\title{
REDUCING SENATORIAL CONTROL OVER PROVINCIAL COMMANDERS: A FORGOTTEN GABINIAN LAW OF 67 BCE
}

\author{
F.J. Vervaet
}

\section{INTRODUCTION}

At two critical junctures in Roman history, M. Tullius Cicero (cos. 63) bitterly complained that Caesar's legally-guaranteed second quinquennium in the Gauls and Illyricum (from 1 March 54 to 1 March 49) had put him in a formidable position of power vis-à-vis a frustrated Senate. ${ }^{* 1}$ On the 9th of December 50, less then a month before the outbreak of civil war between Caesar and his opponents in the Senate, Cicero indicates in $\mathrm{Ad}$ Atticum 7.3.4 (Trebula) that this second five-year term, protected by law, was one of the main factors that had made Caesar nigh-irresistible. He complains,

Cur imperium illi aut cur illo modo prorogatum est? Cur tanto opere pugnatum ut de eius absentis ratione habenda decem tribune pl. ferrent? His ille rebus ita conualuit ut nunc in uno ciui spes ad resistendum sit; qui mallem tantas ei uiris non dedisset quam nunc tam ualenti resisteret.

Why was his command extended, and in such a fashion [i.e., in 55 under the terms of the lex Pompeia Licinia]? Why was there such pressure to get the ten tribunes to bring in the law about his candidature in absentia [i.e., for a second consulship in 52, passed with the support of $\mathrm{Cn}$. Pompeius as consul sine conlega]? By these steps, he has become so strong that hope of resistance now depends on one man; and I would rather that he [i.e., Pompeius] had not given Caesar such formidable strength in the first place than that he should resist him now that he is so powerful.

In Ad Atticum 7.6.2 (Formia, ca. 18 Dec. 50), Cicero repeats the same bitter complaint:

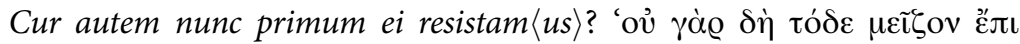
xaxòv' quam cum quinquennium prorogabamus, aut cum ut absentis ratio haberetur ferebamus, nisi forte haec illi tum arma dedimus ut nunc cum bene parato pugnaremus.

${ }^{*}$ All dates are BCE, unless indicated otherwise. 
And why should we start standing up to him now? 'Sure, 'tis no worse a thing' than when we gave him his five years extension or when we brought in the law authorizing his candidature in absentia. Or did we put these weapons into his hands only to fight him now that he is equipped and ready?

In September 44, Cicero again calls to mind in Philippicae 2.24 that Caesar's legally-guaranteed second quinquennium proved a formidable weapon against the Senate:

Duo tamen tempora inciderunt quibus aliquid contra Caesarem Pompeio suaserim; ea uelim reprehendas, si potes: unum ne quinquenni imperium Caesari prorogaret, alterum ne pateretur ferri ut absentis eius ratio haberetur. Quorum si utrumuis persuasissem, in has miseras numquam incidissimus.

However, there were two occasions when I advised Pompeius against Caesar's interests, and you may blame me if you can: one when I advised him not to prorogue Caesar's five-year command, the other when I cautioned him against letting through the proposal that Caesar should be permitted to stand for office in absentia. If he had listened to me on either point, we should never have fallen on these evil times.

Indeed, legally-defined tenure simply meant that the Senate alone could not recall the provincial commander concerned before the expiry date of his term. In this respect, it is also well worth calling to mind that at the beginning of 43, as Caesar Octavianus and Marcus Antonius were still fighting each other, the Senate passed a decree abolishing,

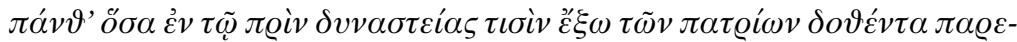

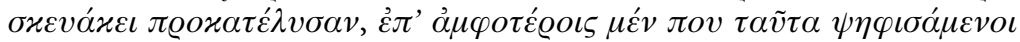

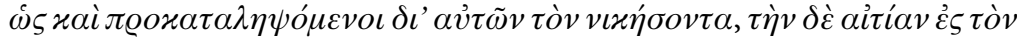

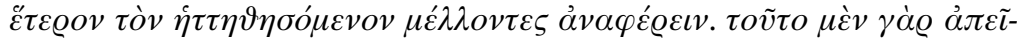

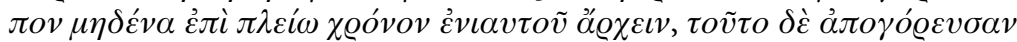

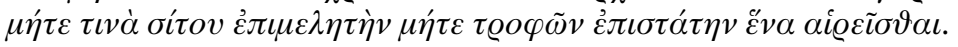

all the privileges the granting of which hitherto to any individuals contrary to established customs had paved the way for supreme power; they voted, of course, that this decree should apply to both parties, intending thereby to forestall the victor, but planning to lay the blame upon the other who should be defeated. In the first place, they forbade anyone to hold office for a longer period than a year, and, second, they provided that no one man should be chosen superintendent of the corn supply or commissioner of food. ${ }^{2}$

\footnotetext{
2 Dio $46.39 .1-3$.
} 
On 27 November of this very same year, the notorious Titian Law would invest Lepidus, Antonius and Octavianus with the infamous Triumvirate for Constituting the Republic, complete with a battery of special powers and a generous quinquennial tempus. ${ }^{3}$

In their quest for precedents and watersheds on the road from Republic to Empire, Roman historians have mostly focused on the notorious lex Gabinia de uno imperatore contra praedones constituendo which resulted in Pompeius' second elected-and thus extraordinary-proconsulate. ${ }^{4}$ In order to facilitate the gigantic task of eradicating piracy across the Mediterranean, one of the law's clauses indeed provided for a triennial tempus. ${ }^{5}$ Regardless of the fact that this lex Gabinia would certainly redefine the concept of extraordinary command, there are good grounds to believe that the historic precedent for the practice of legallydefined provincial tenure was set by another, mostly forgotten, Gabinian Law passed earlier that year. Although P. Willems believed that the lex Gabinia appointing Pompeius to his powerful Mediterranean command also assigned the province of Bithynia to the consul Manius Acilius Glabrio, ${ }^{6}$ the evidence supports R.S. Williams' suggestion that Gabinius carried a separate law "appointing M'. Acilius Glabrio governor of Bithynia-Pontus to succeed L. Licinius Lucullus."7 To my thinking, there are strong indications that this Gabinian law not only assigned a (new) province to one of the consuls of 67 sine sorte, on the model of the notorious lex Manlia of 107, but also that it introduced a couple of momentous novelties in the institutional history of the Roman Republic.

\footnotetext{
${ }^{3}$ For a discussion of the duration of the triumvirate r.p.c as well as the nature of its tempus, see F.J. Vervaet, 'The secret history: the official position of imperator Caesar Divi filius from 31 to $27 \mathrm{BCE}$, Ancient Society 40 (2010), 79-152. For a discussion of how precisely the curatio annonae would from 22 become one of the cornerstones of the Augustan regime, see F.J. Vervaet, 'Arrogating despotic power through deceit: the Pompeian model for Augustan dissimulatio', in A.J. Turner-K.O. Chong-GossardF.J. Vervaet (eds.), Private and Public Lies: The Discourse of Despotism and Deceit in the Ancient World (Leiden-Boston 2010), 136-139.

4 That this probably was the official denomination of this Gabinian Law can be deduced from Cicero, Pro Lege Manilia 52: A. Gabinium [...] de uno imperatore contra praedones constituendo legem promulgasset.

${ }^{5}$ Dio 36.23.4; 34.3; 37.1 and Appian, The Mithridatic Wars 94.

${ }^{6} \mathrm{P}$. Willems, Le Sénat de la République romaine. Sa composition et ses attributions, (Leuven 1883), 586.

7 R.S. Williams, 'The appointment of Glabrio (cos. 67) to the eastern command', Phoenix 38 (1984), 221; 232: Gabinius "simply passed a law altering the province already assigned to Glabrio under the lex Sempronia”. Comp. also V. Mühll, 'Gabinius' (nr. 11), in $R E$, Band 7 (1912), c. 424.
} 


\section{The Political Background: The War AGAINST MithridATES FROM 74 TO 67}

The main issue of this inquiry cannot be properly addressed without a preliminary discussion of the varying fortunes of L. Licinius Lucullus in the East from 74 to 67 . In 74, after intensive lobbying by the consuls, the Senate overturned its previous s.c. de prouinciis consularibus (passed in 75 lege Sempronia) by assigning Cilicia with the war against Mithridates to Lucullus and Bithynia as well as the Propontis with a fleet to his colleague, M. Aurelius Cotta, both assignments being made sine sorte. ${ }^{8}$ By 70, Lucullus commanded an area spanning Asia, Cilicia, Bithynia and Pontus, obviously by virtue of a series of additional senatus consulta. ${ }^{9}$ From the next year onward, however, his formidable position in the East became increasingly contested. ${ }^{10}$ In 36.2.1 f., Dio records that Lucullus' decision to let Tigranes escape triggered the gradual and ultimately complete reduction of his powerful command:

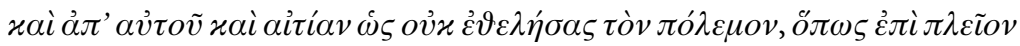

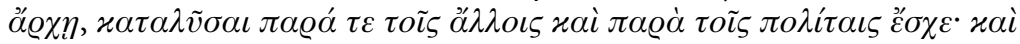

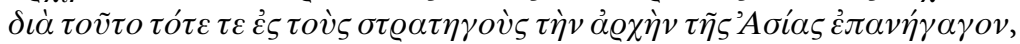

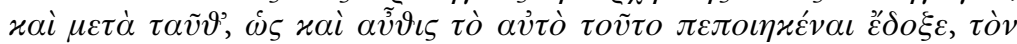

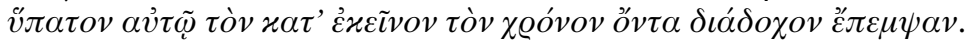

Because of this he was charged by the citizens, as well as others, with refusing to end the war, in order that he might retain his command a longer time. Therefore they at this time [i.e., 69] restored the province of Asia to the praetors, and later, when he was believed to have acted in this same way again, they sent to him the consul of that year to relieve him.

In other words: in what would prove to be just the first stage of the dismantlement of Lucullus' command, the Senate threw the province of Asia into the sortitia praetoria for $69 .{ }^{11}$ In 36.14 .4 , Dio completes this

${ }^{8}$ See Plutarch, Lucullus 5 f.; and T.R.S. Broughton, The Magistrates of the Roman Republic Vol. 2 (Ann Arbor 1968, 2nd ed.) [= MRR 2], 101. For the fact that the Sempronian Law concerning the consular provinces did not prohibit assignments of consular provinces sine sorte, either before or after the consuls concerned had assumed office, see F.J. Vervaet, 'The scope of the lex Sempronia concerning the assignment of the consular provinces (123 BCE)', Athenaeum 94 (2006), 627-656.

${ }^{9}$ Broughton 1968, op. cit. (n. 8), 129.

${ }^{10}$ See Williams 1984, op. cit. (n. 7), $222 \mathrm{f}$. for a good outline of the reasons for the decreasing popularity of Lucullus in Rome and abroad, for which Lucullus was at least partially to blame himself.

${ }_{11}$ Williams 1984, op. cit. (n. 7), 223 accepts the suggestion of E. Badian, Publicans and Sinners: Private Enterprise in the Service of the Roman Republic (Ithaca 1972), 98; 151 
picture by recounting that in 67 , Lucullus' soldiers grew restive again "largely because they heard that Acilius, the consul, who had been sent out to relieve Lucullus for the reasons mentioned [in 36.2.1 f., supra], was drawing near, and they accordingly regarded Lucullus with contempt, as being already a mere private citizen." 12 The complement of both passages shows that Lucullus was to be succeeded altogether by M'. Acilius Glabrio, one of the consuls of 67. Dio goes on to explain in 36.15.1 that Lucullus' position grew even weaker as "Marcius [Rex], Acilius' predecessor, who was on his way to Cilicia, his destined province, had refused a request of his for aid." 13 Although Marcius Rex must have received Cilicia as consul in 68 , he had apparently reached his province only at some point early in 67 , shortly before Glabrio was to arrive in his. ${ }^{14}$ This means that Glabrio must have been charged with Lucullus' command early in 67 and had rushed off to his province at his earliest convenience, planning to spend the better part of his consulship in the East.

that the publicani were the driving force behind this allocation of Asia to a new governor, in casu one of the praetors of 69. In Lucullus 20.4 f., Plutarch relates that the publicani in Asia were outraged by Lucullus' measures to reduce the public debt of the Asian cities and began lobbying against the proconsul at Rome. Plutarch explains that they bribed some of the tribunes to proceed against Lucullus as they were men of great influence who got many of the active politicians into their debt. A. Keaveney, Lucullus: A Life (LondonNew York 1992), 115 suggests that Asia was withdrawn from Lucullus' command by means of a plebiscite early in 68. Although this powerful coalition of publicans and tribunes of the plebs indeed successfully pressured the Senate in 69 to reduce Lucullus' provincial command, there is no conclusive proof of a plebiscite at this stage.

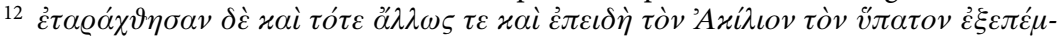

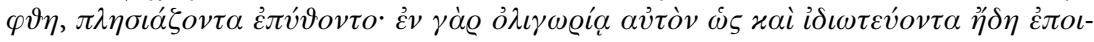
ovvขนo.

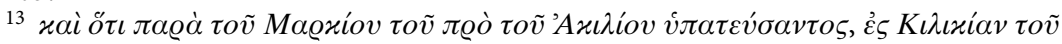

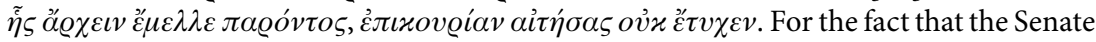
had authorized Marcius Rex to conscript the huge force of three legions for service in Cilicia, see Sallust, Historiae 5, frag. 14 (ed. Maurenbrecher 1891, 194): At Lucullus audito Q. Marcium Regem pro consule per Lycaoniam cum tribus legionibus in Ciliciam tendere. In 36.17.2, Dio further adds that Marcius turned Lucullus' request for help down on the pretext that his troops refused to follow him (to render assistance to Lucullus). Instead, he went straight to Cilicia where, adding insult to injury, he received a prominent deserter from Tigranes as well as the young P. Claudius Pulcher, who had deserted Lucullus because of his subversive role in the mutiny at Nisibis.

${ }^{14}$ Marcius' rather late departure for Cilicia must have been due to the fact that he held office alone for the greater part of his tenure. His colleague, L. Caecilius Metellus, died early in the year and the suffect consul designate died before entering upon his office: Dio 36.4.1. In all likelihood, this sequence of ominous events caused the Senate to consult the augural college, who then formally advised against any further attempt to get Metellus replaced. 
In sum, this brief analysis reveals that in 69 , the Senate had not only decided to make Asia prouincia praetoria, but also assigned Cilicia as one of the consular provinces for 68 under the terms of the Sempronian Law. ${ }^{15}$ Although Lucullus would thus be gradually deprived of Asia and Cilicia, the Senate did leave him in command of Bithynia and the bellum Mithridaticum in Pontus and its periphery. This strongly suggests that they still wanted to give the besieged proconsul the opportunity to take full credit for his troubles by putting an honourable end to the war against Mithridates and Tigranes. ${ }^{16}$ The Senate's intentions, however, were soon to be thwarted as one of the consuls of 67 got the remainder of Lucullus' command and hurried to secure his prize.

In Pro Lege Manilia 20-26, Cicero produces a striking survey of the political and military situation in Asia Minor until the spring of 67, when total chaos seemed to be imminent. Cicero begins to tell how Lucullus conducted an initially highly successful campaign which culminated in the conquest and sack of Pontus, the heartland of Mithridates' kingdom, including the capture of a series of Pontic cities and Cappadocian towns. Mithridates ultimately had to flee to Tigranes the Great, who had turned Armenia into a formidable regional power. As Tigranes overconfidently refused to extradite Mithridates, Lucullus promptly invaded Armenia. After the conquest of Tigranocerta, however, mutiny put an inglorious end to Lucullus' triumphant advance. Livy's epitomator indicates that this insubordination chiefly was the work of the two so-called 'Valerian' legions, who insisted that their term of service had expired. ${ }^{17}$ At the same time, Mithridates, resilient as ever, returned to Pontus in command of a

\footnotetext{
15 See MRR 2, 137; 139. Broughton seems to think that Marcius got Cilicia extra sortem in 68. Unfortunately, it is impossible to establish whether or not the consuls of 68, L. Caecilius Metellus and Q. Marcius Rex, had proceeded to the sortitio consularia immediately upon entering their office. In case the consuls had not cast lots before Metellus' untimely death, it is possible that Marcius Rex was allowed to take his pick from the provinces assigned the year before lege Sempronia, or that the Senate indeed passed a new decree, assigning Cilicia to Marcius Rex sine sorte. I am inclined to believe that Cilicia was assigned in 69 lege Sempronia, and that the consuls of 68 duly cast lots for their prouinciae at some point early in their tenure. See Vervaet 2006, op. cit. (n. 7) for a discussion of how the time and actual order of the decrees on the consular and praetorian provinces, the sortitio consularis/praetoria, the prorogatio imperii of the various imperators in the field and the ornatio prouinciarum were always fully at the discretion of the Senate and could vary substantially.

${ }^{16}$ See Plutarch, Lucullus 35.7 (infra) for the fact that the nobles were dismayed at what they believed to be Lucullus' wrongful succession by Pompeius in 66 .

${ }_{17}$ Periochae 98: duae legiones Valerianae, quae impleta a se stipendia dicentes Lucullum reliquerunt.
} 
new army consisting of Pontic troops and soldiers provided by Tigranes and his vassals. At the beginning of 67 , Mithridates even managed to inflict a crushing defeat upon the army of C. Valerius Triarius, one of Lucullus' legates. ${ }^{18}$ In Pro Lege Manilia 26, Cicero implicitly indicates that around the very time of this disastrous defeat, Lucullus was robbed of the remaining part of his once powerful command by the Comitia, who compelled the proud proconsul to demobilize those troops who had served their time and hand over the rest to Manius Acilius Glabrio:

Hic in illo ipso malo grauissimaque belli offensione Lucullus, qui tamen aliqua ex parte iis incommodis mederi fortasse potuisset, uestro iussu coactus, quod imperi diuturnitati modum statuendum uetere exemplo putauistis, partem militum qui iam stipendiis confectis erant dimisit, partem M'. Glabrioni tradidit.

Here in the very hour of disaster and of a most serious reverse, because you thought that, out of deference to old precedent, some limit should be set on his long tenure of command, Lucullus - a man who might perhaps have been able in some measure to repair these losses-was by your orders compelled to disband a part of his troops, who had served their time, and to hand over a part to Manius Glabrio.

Cicero next indicates that Glabrio was in for a particularly rough ride in Asia Minor:

Multa praetereo consulto, sed ea uos coniectura perspicite quantum illud bellum factum putetis quod coniungant reges potentissimi, renouent agitatae nationes, suscipiant integrae gentes, nouus imperator noster accipiat uetere exercitu pulso.

There is much that I leave out on purpose: you must supply the omission for yourselves and realize what magnitude this war must have attained when it is waged in concert by two most powerful kings, renewed by tribes in ferment, taken up by fresh nations and entrusted, after the defeat of the old army, to a new Roman imperator.

This evidence unambiguously confirms that, early in 67 , a popular vote terminated Lucullus' provincial command altogether by transferring it to the consul M'. Acilius Glabrio. ${ }^{19}$ Another fragment from Sallust's Histories

18 In Pro Lege Manilia 25, Cicero clearly reveals the magnitude of this reverse: Sinite hoc loco, Quirites, sicut poetae solent qui res Romanas scribunt, praeterire me nostram calamitatem, quae tanta fuit ut eam ad auris [L. Luculli] imperatoris non ex proelio nuntius sed ex sermone rumor adferret. Cf. also Appian, The Mithridatic Wars 89 and Plutarch, Lucullus 35.1 for the notoriously serious character of this defeat.

19 In point of fact, Cicero had already indicated in Pro Lege Manilia 5 that Acilius Glabrio was appointed to replace Lucullus as commander-in-chief in the war against 
corroborates and completes Cicero's evidence since it tells us that Legiones Valerianae comperto lege Gabinia Bithyniam et Pontum consuli datam, sese missos esse: "The legions of Valerius, when it had been discovered that (the province of) Bithynia and Pontus had been given to the consul by a Gabinian Law, that they [reading sese after Douza] had been discharged." 20 The brevity of this bit of information is inversely proportional to its importance. It not only shows that Acilius was given Bithynia and Pontus with the war against Mithridates and Tigranes by virtue of a Gabinian Law, but also that this statute contained a number of accurate provisions concerning the army of Lucullus and Acilius Glabrio. The statute therefore did more than just transferring Lucullus' command to one of the consuls of 67 . This, then, begs the question of the precise nature of its additional provisions.

However, before addressing this key issue, it not unimportant to point out that the chief aim of this Gabinian Law, viz. Lucullus' replacement in the war against Mithridates by the consul M'. Acilius Glabrio, never materialized. After explaining how the imminent arrival of the consul rekindled the mutiny in Lucullus' army (supra), Dio notes in 36.15 .3 that the 'Valerians' withdrew altogether when they learned that they had been discharged by the authorities at home. ${ }^{21}$ In 36.17 .1 , Dio explains that as a direct result of this desertion, Mithridates managed to recover most of his domain and to invade Cappadocia, "since neither Lucullus defended it, on the ground that Acilius was near, nor yet Acilius himself." According to Dio, the latter had at first been hurrying to rob Lucullus of the victory, whereas after he learned what had actually taken place he did not venture to come to the camp but delayed in Bithynia. In all probability, tidings of Triarius' crushing defeat and renewed mutiny in Lucullus' army made the consul reconsider. This shows that Acilius had been blissfully unaware of the reality in the field before arriving in Bithynia. In a similar vein, Plutarch recounts in Luc. 35.5 f. how the traditional commission of decem

\footnotetext{
Mithridates and Tigranes: L. Lucullum magnis rebus gestis ab eo bello decedere; huic qui successerit, non satis esse paratum ad tantum bellum administrandum. Compare also a concise but clear reference in Scholia Gronoviana Pompeiana $\$ 26$ p. 319 (ed. Stangl 1912): Nouus imperator. Glabrio. For a late antique allusion to Lucullus' replacement by one of the consuls of 67, see Eutropius 6.9.3: Lucullo paranti capta Nisibi contra Persas successor est missus.

${ }^{20}$ Historiae 5, frag. 13 (ed. Maurenbrecher 1891, 194)-I warmly thank my colleague, Dr. Andrew Turner, for his valuable assistance with translating this rather difficult excerpt.

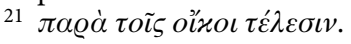


legati cum auctoritate, sent by the Senate to regulate the affairs of Pontus on the supposition that it was a secure Roman possession, ${ }^{22}$ too, were in for a rather unpleasant surprise. To their utter astonishment, they found that, while Tigranes was ravaging Cappadocia and Mithridates tried to recover his former power, Lucullus had become the risée of his own army. The sudden turn for the worse in the East in the spring of 67 apparently came as a complete surprise to outsiders, friend and foe alike. The instability of the army was, perhaps, the most important rationale behind Acilius' decision to remain in Bithynia and, perhaps, wait for the storm to blow over. After all, years of bitter fighting had brought Mithridates on the verge of exhaustion, regardless of his crushing defeat of Triarius. His successes in the spring of 67 were largely due to the subversive inaction of Lucullus' army. Indeed, when Pompeius refused to come to terms with Mithridates in 66, the latter immediately took to his heels again. ${ }^{23}$

\section{The Scope of the Gabinian LaW}

The lex Gabinia de permutatione prouinciae M'. Acilii Gabrionis was one of the highlights of popularis agitation against Lucullus. ${ }^{24}$ In $L u c .33 .4 \mathrm{f}$., Plutarch recounts that Lucullus' army, dissatisfied with his arrogant austerity, ${ }^{25}$ got the vigorous backing of popular leaders at Rome. These envied Lucullus and denounced him for protracting the war through enjoyment of power and greed. They portrayed Lucullus as the absolute

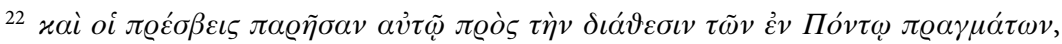
$\omega \varsigma \delta \dot{\eta} \beta \varepsilon \beta \alpha i \omega \varsigma \dot{\varepsilon} \chi \sigma \mu \varepsilon \dot{v} v \omega v$. As Plutarch points out that Lucullus himself had reported to the Senate that Tigranes had been completely subdued, it is obvious that the proconsul's victorious missives about Mithridates had been equally premature.

${ }^{23}$ Dio 36.45 .

${ }^{24}$ See esp. R.S. Williams, Aulus Gabinius: A Political Biography (Diss. Michigan State University 1973), $48 \mathrm{f}$. for a good discussion of the political context and Gabinius' political methods. Since, in all likelihood, the Senate had already defined the consular provinces lege Sempronia in 68, this lex Gabinia probably was a lex de permutatione prouinciae. Nonetheless, the possibility that it was a lex de bello Mithridatico M'. Acilio Glabrione extra ordinem mandando (on the analogy with the notorious Manilian Law of 66-see Asconius (ed. Orellius 1833, 66): altera de bello Mithridatico Cn. Pompeio extra ordinem mandando, ex qua lege tum Magnus Pompeius bellum gerebat) cannot be ruled out altogether.

${ }^{25}$ In fact, Dio in 36.16 ascribes Lucullus' embarrassing failure to maintain the loyalty of his troops, costing him the chance to conclude his brilliant campaign gloriously, entirely to his demanding, haughty, stingy and harsh disposition. See, for example, Plutarch, Lucullus 14.2 for war booty and loot providing a vital source of income for the rank and file at the time. 
ruler of Cilicia, Asia, Bithynia, Paphlagonia, Galatia, Pontus, Armenia and the regions extending to the Phasis, and declared that the sacking of Tigranes' palaces suggested that he had been sent to strip the kings, not to subdue them. According to Plutarch, these were chiefly the accusations of L. Quinctius, ${ }^{26}$ "one of the praetors, to whom most of all the People listened when they passed a vote to send men who should succeed Lucullus in the command of his province. They also voted", Plutarch adds, "that many of the soldiers under him should be released from military service." ${ }^{27}$ In Luc. 35.1-3, Plutarch clarifies that, after their mutiny at Nisibis during the winter of $68 / 67$, the troops returned to their standards following Mithridates' defeat of M. Fabius Hadrianus and his march against Sornatius and Triarius, and departed with Lucullus to settle scores with Mithridates. However, while Lucullus was marching back to deal with Tigranes before he could join forces with Mithridates, the 'Fimbrians' mutinied and left their ranks, declaring "that they were discharged from service by decree, and that Lucullus no longer had the right to command them, since his provinces had been assigned to others." ${ }^{28}$ In Mithr. 90, Appian, too, records that shortly after the defeat of Triarius, when Lucullus was already encamped near Mithridates, the proconsul of Asia sent heralds to proclaim that the Romans had accused Lucullus of needlessly prolonging the war, and had ordered that the soldiers under him be dismissed, and that the property of those who did not obey this order should be confiscated. ${ }^{29}$ Appian adds that the troops concerned disbanded at once, except a few who remained with the proconsul because they were very poor and did not fear the penalty.

\footnotetext{
${ }^{26}$ For Plutarch's L. Quintus being really L. Quinctius, see (the sources listed in) MRR 2, 103.

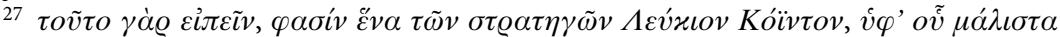

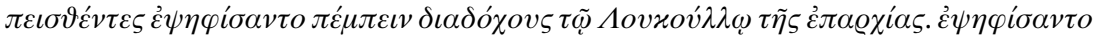

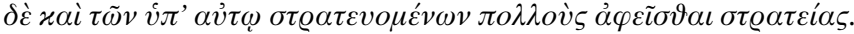

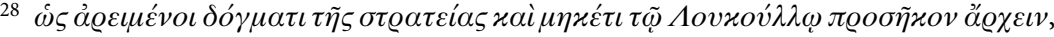
$\dot{\varepsilon} \tau \varepsilon \dot{\varepsilon} \varrho \circ \iota \varsigma \alpha \dot{\pi} \pi o \delta \varepsilon \delta \varepsilon \iota \gamma \mu \varepsilon \dot{\varepsilon} \omega \nu \tau \tilde{\omega} v \dot{\varepsilon} \pi \alpha \varrho \chi \iota \tilde{\omega} v$.

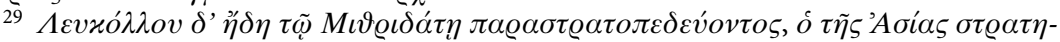

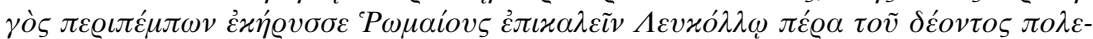

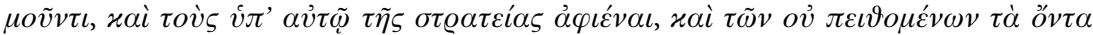

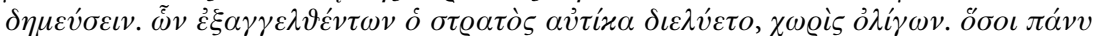

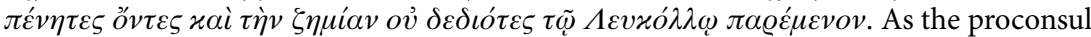
of Asia probably sent this message early in 67, it obviously regards the praetor who had drawn prouincia Asia in 69. See MRR 2, 132; 139 for the plausible suggestion that the proconsul involved was P. Cornelius Dolabella. This eagerness on behalf of the proconsul of Asia suggests that he was hostile to Lucullus.
} 
For the sake of this argument, it is not unimportant to point out that some confusion has crept into Plutarch's account. First, Plutarch's representation in $L$ uc. $33.4 \mathrm{f}$. might create the impression that as early as in 69 a plebiscite had assigned one or both consular provinces at the expense of Lucullus. The explicit connection between the dispatch of 'successors' for Lucullus and the demobilization of a considerable part of his army, however, strongly suggests that Plutarch refers to the popular vote of 67 on behalf of Acilius Glabrio. Plutarch seems to confuse the events of 67 with the Senate's decision of 69 to assign Cilicia as one of the consular provinces for 68. In Luc. 33.4, Plutarch simply recapitulates the case made by Lucullus' enemies before the Senate decided to withdraw Asia and Cilicia from his command. ${ }^{30} \mathrm{~L}$. Quinctius was thus praetor in either 69, since both Cilicia and Asia were mentioned in what reportedly was his speech, or 67 , as his agitation is explicitly linked to the popular vote to send 'successors' to the command of Lucullus. ${ }^{31}$ At any rate, it is clear that Quinctius carried much weight with the commons and that the decrees of 69 concerning Asia and Cilicia were passed under strong popular pressure. ${ }^{32}$ Still not satisfied with the quite substantial reduction of Lucullus' command of 69 , his opponents in Rome and abroad relentlessly continued to undermine him through 68 and finally won a complete victory at the outset of 67 . Plutarch's twofold reference to 'successors' for Lucullus' 'provinces, ${ }^{33}$ too, can be explained easily. Both in $69 / 68$ and at the beginning of 67 , successors indeed arrived successively for Asia (one of the praetors of 69), Cilicia (one of the consuls of 68) and Bithynia (one of the consuls of 67). Plutarch made the error of

30 Williams 1984, op. cit. (n. 7), 223, n. 10 argues that Plutarch here confounds the events of two years, and that the reference to the release of some of Lucullus' troops from military service regards "surely a confusion with the release of the Valerians by Gabinius the following year".

31 Contra MRR 2, 138; Keaveney 1992, op. cit. (n. 11), 115, who range L. Quinctius among the praetors of 68. Mühll 1912, op. cit. (n. 7), c. 424 dates the praetorship of L. Quinctius correctly to 67. It is perfectly possible that L. Quinctius had already been vociferously opposing the position and policies of Lucullus in 69, making the argument paraphrased by Plutarch, and subsequently gave his full backing to Gabinius' bill to terminate Lucullus' command as praetor in 67.

32 Cf. MRR 1, 101; 103 (where Broughton more cautiously asserts that Quinctius was praetor in " 68 or 67 ") for the fact that Lucullus as consul checked an attempt on the part of the tribune of the plebs L. Quinctius to restore the powers of the tribunate. Since we do not hear of him anymore in the context of the leges Gabinia and Manilia on behalf of Pompeius, Quinctius apparently acted primarily out of rancour towards Lucullus.

${ }^{33}$ Cf. Lucullus 33.5; 35.3, quoted in the above. 
ascribing all three of these appointments to the same popular vote. Furthermore, a commission of decem legati cum auctoritate was dispatched at the very latest in 68 to assist Lucullus in his capacity of proconsul of Bithynia with the task of reorganizing Pontus and the surrounding regions. ${ }^{34}$ That some of Lucullus' closest connections were among the appointees ${ }^{35}$ confirms the suspicion that, regardless of the gradual reduction of Lucullus' sphere of command, the Senate still wanted him to put a glorious end to the war. ${ }^{36}$ Although increasing popular and equestrian pressure may partially explain the assignments of 69 (Cilicia prouincia consularis for 68 and Asia prouincia praetoria for 69), these decisions probably also resulted from Lucullus' own optimistic reports of that year. As a matter of fact, Machares' request for Pontus to be enrolled amongst Rome's friends and allies made Lucullus decide that the war against Mithridates was finished and prompted him to invade Armenia. This campaign culminated in the defeat of Tigranes near Tigranocerta on the sixth of October $69 .{ }^{37}$ The fact that the Senate in 68 authorized Marcius Rex to raise the considerable force of three legions in order to quash piracy in Cilicia further underscores their genuine belief that the time was ripe for an overall reorganization of the troubled peninsula. ${ }^{38}$

${ }^{34}$ Williams 1984, op. cit. (n. 7), 223 suggests that by requesting for a commission of decem legati, Lucullus "had given his political enemies justification for charges that he was needlessly prolonging the war". In my view, quite the opposite is true.

${ }_{35}$ Ad Atticum 13.6a (June 45): atque hoc etiam accepi, non solitos maiores nostros eos legare in decem qui essent imperatorum necessarii, ut nos ignari pulcherrimorum institutorum aut neglegentes potius M. Lucullum et L. Murenam et ceteros coniunctissimos ad L. Lucullum misimus. These words also show that such commissions of decem legati ex $S C$, mandated to settle the affairs of a conquered area or a shattered province, were still common practice during the last century of the Republic.

${ }^{36} M R R 2,129(+$ n. 6, 131) dates the appointment of the decem legati to 70, arguing that the favourable composition of the commission "suggests the leadership of the consuls of 69 rather than of 70 , yet a political climate in Rome more favorable than that which set in in 69." In light of the fact that the Senate at any rate wanted Lucullus to complete his achievements against Mithridates, both 69 and, perhaps more plausible, 68 are perfectly feasible.

${ }^{37}$ Cf. Plutarch, Lucullus 24.1; 27.7.

${ }^{38}$ For the plausible suggestion that Marcius' powerful Cilician command was primarily aimed at eradicating piracy in that region, see Keaveney 1992, op. cit. (n. 11), 124 "Rex's brief was to fight the pirates in Cilicia". Precisely one year later, Cn. Pompeius would conduct a sweeping campaign against the strongholds of Cilician piracy. Besides, the Senate had already demonstrated its determination to gain control of the Anatolian coastal waters in 73, when it proposed to vote no less than 3,00o talents to provide Lucullus with an adequate fleet for the war against Mithridates. According to Plutarch, Lucullus 13.4, this motion was eventually dropped since Lucullus himself wrote a letter in which he 
Most importantly, however, Plutarch and Appian not only confirm that Lucullus was to be replaced altogether by vote of the People, but also that this statute at once ordered the demobilization of a part of his army. Under normal circumstances, the arrival of the consul Acilius Glabrio in his province in the spring of 67 would have officially terminated Lucullus' command in Asia Minor. Since the Gabinian Law ordered the dismissal of a great number of Lucullus' soldiers ${ }^{39}$ and Acilius himself assumed that he would easily gain the final victory against two kings widely believed defeated, ${ }^{40}$ the plan clearly was to rob Lucullus of the crowning glory of his campaign. In all likelihood, Acilius Glabrio was to impose the leges pacis on the vanquished kings, possibly in cooperation with the legati cum auctoritate dispatched in $68 .{ }^{41}$ This bold intervention on the part of the populares was a direct assault on Lucullus' dignity. Once confronted with reality in the field, however, Acilius deemed it wiser to remain in Bithynia, ${ }^{42}$ so delaying the traditio imperii in the war against Mithridates. Lucullus' own decision to remain in Cappadocia with his unruly army, in the midst of a very chaotic situation, may suggest that he still nursed hopes that he would eventually be reinstated as commander in the war against Mithridates and Tigranes. ${ }^{43}$

stated that he would drive Mithridates from the sea without such costly array, using only allied naval forces. Last but not least, the fact that Marcius Rex put P. Claudius Pulcher in command of his fleet in 67, leading to the latter's abduction by pirates (Dio 36.17.2 f.), also suggests that Marcius had been sent to Cilicia with a mandate to crush the infamous Cilician praedones. All this indicates that in 69/68, when the stage seemed to have been set for the restoration of law and order across Asia Minor, the Senate had also decided to destroy the threat of Cilician piracy.

${ }^{39}$ Williams 1984, op. cit. (n. 7), 226 points out that, as far as we know, Acilius was not given any new troops.

${ }^{40}$ M. Gelzer, Das erste Consulat des Pompeius und die Übertragung der großen Imperien (Berlin 1943), 31 rightly suggests that the clause of the law concerning the so-called Valerian legions shows that authorities in Rome underestimated the military situation in the East and had not factored the change for the worse.

${ }^{41}$ Since Acilius Glabrio owed his command to a plebiscite passed early in 67 against the will of the Senate (cf. infra) and they had already dispatched legati cum auctoritate mandated to reorganize affairs in Asia Minor in cooperation with Lucullus, 'the Senate's proconsul', a collision between this plenipotentiary commission and Glabrio was written in the stars. For an excellent study on the role of such senatorial embassies in the administration of the provinces and in particular the nature of the so-called leges prouinciae, see D. Hoyos, 'Lex Provinciae and governor's edict', Antichton 7 (1973), 47-53.

${ }^{42}$ See Williams 1984, op. cit. (n. 7), 226 for a good description of the hopeless situation confronting Glabrio at the time of his arrival.

${ }^{43}$ Comp. also Lucullus 35.4-6, where Plutarch records that at the behest of the other troops, the legally dismissed soldiers agreed to remain during the summer provided they 
Equally importantly, there is some good circumstantial evidence for supposing that the Gabinian Law on behalf of Acilius Glabrio also broke new ground in that it contained a clause concerning the duration of his provincial tenure. First, Dio records in $36.42 .4-43.2$ that, at the very outset of 66, the tribune of the plebs C. Manilius, in a drastic bid to secure the support of Gabinius and Pompeius, "went so far as to offer him command in the war against Tigranes and that against Mithridates, and the governorship of Bithynia and Cilicia at the same time." Dio goes on to say that,

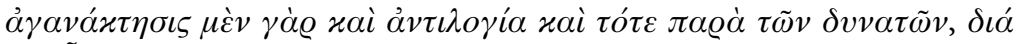

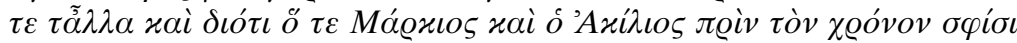

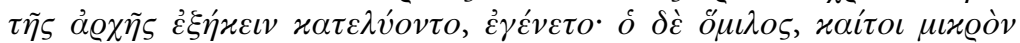

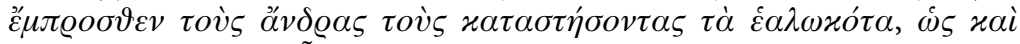

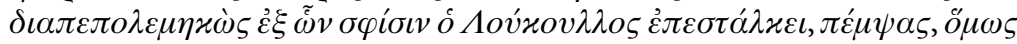

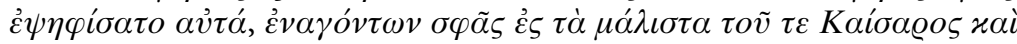

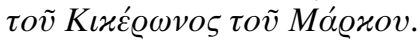

Now indignation and opposition were manifest even then on the part of the optimates, particularly because Marcius and Acilius were being removed before the period of their command had expired. ${ }^{44}$ But the populace, although a little earlier it had sent the proper officials to establish a government over the conquered territory, regarding the war as at an end from the letters which Lucullus sent them, nevertheless voted to do as Manilius proposed. They were urged to this course very strongly by Caesar and Marcus Cicero. ${ }^{45}$

On the one hand, Dio's valuable note implies that the imperium of Marcius Rex had probably been prolonged in annum in 67, which meant that he was normally entitled to govern Cilicia as proconsul throughout 66 .

were to be discharged if no enemy should come down to fight them. After the expiration of this agreed term, the vast majority of these soldiers in rather theatrical fashion discharged from service.

${ }^{44}$ See Suetonius, Diuus Iulius 8 for the Latin equivalent being ante tempus: before the expiry of the officially defined term.

45 Dio here wrongly suggests that the senatorial commission, too, had been constituted and sent out by virtue of a popular vote. It should not be doubted that it was dispatched by decree of the Senate some time before Gabinius passed his law on behalf of Acilius Glabrio. First, Dio himself notes in 36.46.1 f. that Lucullus in 66 tried to convince Pompeius that the whole conflict was over and that there was no further need of an expedition, and that for this reason the men sent by Senate to arrange for the government

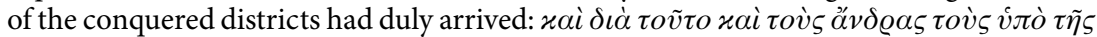

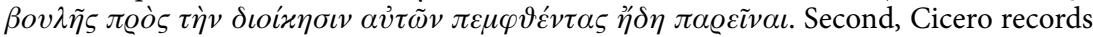
in Ad Atticum 13.6a (June 45, quoted in n. 35) that some of Lucullus' closest connections served in this commission. This positively rules out the possibility that they had been sent by the People as part of the campaign to deprive him of his responsibilities in the East. 
On the other hand, it also indicates that the Gabinian Law had defined a tempus for Glabrio's command in Bithynia and the bellum Mithridaticum. Second, there is the fact that the subsequent and famous lex Gabinia de uno imperatore contra praedones constituendo amongst other things empowered the proconsul Pompeius to exercise his imperium in the war against the pirates in triennium. Therefore, it is quite likely that the Gabinian Law concerning Glabrio's province contained an analogous clause authorizing him to administer Bithynia and the war against Mithridates in triennium, i.e., for three consecutive years. Admittedly, the Senate themselves had first introduced the practice of triennial provincial tenure on behalf of $\mathrm{Cn}$. Pompeius and M. Antonius Creticus in 77 and 74 respectively. ${ }^{46}$ The critical difference, though, was that the Senate could always revise their own decisions whereas they could not alter the provisions of statute law. Finally, it is important to point out that the Gabinian law concerning Glabrio's consular province was most probably passed inuito senatu, against the will of the Senate. In Luc. 35.7, Plutarch explains that the Senate, and the nobiles in particular, felt aggrieved about Lucullus' succession by Pompeius in 66 and considered the former a wronged man, because they believed that he had been superseded in a triumph, not in a war, and that he had been forced to relinquish and turn over to others the prizes of victory in his campaign, and not his campaign itself. By analogy, it is reasonable to suppose that the Gabinian Law on behalf of the consul Acilius Glabrio must have met with similar objections from the Senate, especially as the military situation had seemed much better at the turn of 68/67. Given these circumstances, it would have made perfect sense to protect Glabrio's provincial tenure legally so as to preclude any premature senatorial attempts to have him recalled or replaced.

It should not be doubted that this Gabinian Law was passed sometime at the very beginning of the year 67 . Dio, whose chronologically organized account of this year runs from 36.12 to 36.42.2, mentions the imminent arrival of Acilius Glabrio in Bithynia 36.14.4-15.1, at a time when Q. Marcius Rex had not yet arrived in Cilicia. This suggests that the Gabinian Law must have been passed around, perhaps, February 67. Since Acilius subsequently departed for Bithynia at his earliest

${ }^{46}$ For Pompeius initially being granted a triennial tenure against Sertorius in 77 , see F.J. Vervaet, 'Pompeius' career from 79 to 7 о BCE: constitutional, political and historical considerations', Klio 91 (2009), 419-422; for M. Antonius ( $p r$. 74) being given his command against the pirates in triennium, see Velleius 2.31.2-4. 
convenience he had probably arrived in his province by May at the latest. ${ }^{47}$ By analogy with the scope of the tempora legitima as defined by the leges Vatinia and Pompeia Licinia of 59 and 55 successively, which notoriously authorized Caesar to govern his provinces from 1 March 59 to 1 March 54 and then again from 1 March 54 to 1 March $49,{ }^{48}$ it is quite possible that this Gabinian law entitled Acilius to exercise his imperium in Bithynia and the war against Mithridates from, for example, 1 April 67 to 1 April $64 .{ }^{49}$ This generous term would give him ample opportunity to end the war in eastern Asia Minor and so secure a public triumph, to reorganize the region in accordance with the best interest of the forces which had backed him, and, last but not least, to enrich himself.

\section{CONCLUSIONS}

Precisely forty years after the lex Manlia had transferred prouincia Africa and the war against Iugurtha from the proconsul Q. Caecilius Metellus Numidicus (cos. 109) to the consul C. Marius, ${ }^{50}$ a similar plebiscite transferred Bithynia with the war against Mithridates from the proconsul Lucullus to the consul Acilius Glabrio. Another striking parallel was that this plebiscite, too, was passed against the will of the Senate and with strong popular and equestrian backing. In terms of its scope, however, this Gabinian Law represents another important milestone in Roman history. In his famous analysis of the Roman polity as the prototype of composite, well-balanced constitution, Polybius explains that the Senate essentially had three instruments to keep the consuls-and by extension all imperatores cum prouincia-in check: namely its traditional discretion in all matters pertaining to (1) the ornatio prouinciae (stipendium, uestimenta \& frumentatio); (2) the tempus imperii (through its decisions on prorogatio imperii); and (3) the ratification of the commanders' acts and grants of public funds for triumphs. ${ }^{51}$ As the provisions of the Gabinian Law defined the consul's ornatio prouinciae as well as a legally-guaranteed

\footnotetext{
47 Williams 1984, op. cit. (n. 7), 221; 224, too, believes that this law was voted "Early in 67 ", and that the Gabinian law on piracy followed "later in the spring of 67 ". Williams (226) supposes that Glabrio left Rome in the spring of 67.

${ }^{48}$ A discussion of the termini of Caesar's successive quinquennial terms in the Gauls and Illyricum is beyond the scope of this inquiry.

49 This would further explain why the consul was in such a hurry to make it to his province in 67: he wanted to make the most of his legally-guaranteed triennial tenure.

${ }^{50}$ See $M R R$ 1, 550.

${ }^{51}$ Polybius 6.15.2-8.
} 
minimum term for his provincial command, two of these fundamental pillars of senatorial control were for the first time undermined simultaneously. While the first arrangement was, perhaps, modeled on the notorious lex Sulpicia of 88 , which transferred the command against Mithridates from the consul Sulla to the extraordinarily appointed proconsul Marius, ${ }^{52}$ the additional establishment of a legally-defined tempus imperii represents an important precedent. By virtue of this clause, the position of Acilius Glabrio in Bithynia was secure vis-à-vis the Senate and this from some time early in 67 to some time early in 64 . It therefore was this Gabinian Law rather than its successor concerning the war against piracy ${ }^{53}$ which served as the pioneering, if largely forgotten, model for Caesar's legally-guaranteed quinquennial commands in the Gauls and Illyricum, and, ultimately, the successive long-term provincial commands granted to Augustus. Regardless of the fact that the Senate had set the precedent for triennial provincial tenure in 77 and 74 , this Gabinian Law, passed hardly three years after the restoration of the tribunicia potestas, thus was a remarkable and audacious piece of legislation.

On the one hand, Acilius Glabrio was no part of the pauci potentes who dominated the Senate around 67, regardless of his noble ancestry. ${ }^{54} \mathrm{On}$ the other hand, as regards the question of the extent of Pompeius' involvement in the run-up and vote of this lex Gabinia, this analysis corroborates Williams' cogent argument that Acilius Glabrio did not receive the command against Mithridates as Pompeius' "place holder", ${ }^{55}$ and that one may

52 Appian's note in Bella Ciuilia 1.57 that the legionaries encamped at Nola feared that Marius might enlist other soldiers instead of themselves strongly suggests that the Sulpician Law had transferred the six legions of the consular army to Marius, authorizing him to replace or supplement the legions as he saw fit.

${ }^{53}$ So E. Badian, 'The young Betti and the practice of history', in G. Crifò (ed.), Costituzione Romana e Crisi della Repubblica (Perugia 1986), 84 and K.M. Girardet, 'Imperium 'maius'. Politische und Verfassungsrechtliche Aspekte. Versuch einer Klärung', in Fondation Hardt pour l'Étude de l'Antiquité Classique, Entretiens, Tome XLVI: La Révolution Romaine après Ronald Syme (Genève 2000), 184 n. 55.

${ }^{54}$ See, for example, Gelzer 1943, op. cit. (n. 40), 30; and Williams 1984, op. cit. (n. 7), $231 ;$ n. 48.

${ }^{55}$ For this line of thought, see, amongst others, J.M. Cobban, Senate and Provinces $78-$ 49 BC. Some aspects of the foreign policy and provincial relations in the Senate during the closing years of the Roman Republic (Cambridge 1935), $123 \mathrm{f}$., who argues that Pompeius did not receive Lucullus' command in 67 in order not to snub the Senate needlessly: "Glabrio was deliberately chosen, without his own knowledge, to keep the place warm for Pompey. Certainly, there could have been no better choice; for while his known integrity lulled the Senate into acquiescence, his constitutional laziness and indecision 
not consider this Gabinian law as "part of a single, far-sighted scheme, as many believe", but as "one of a series of fortunate circumstances which Pompeius shrewdly manipulated to his own advantage." To my thinking, Williams rightly concludes that,

"To see Pompeius as a Machiavellian overlord with the foresight to know how events in the East would stand in 66 is to exaggerate grossly his abilities. That Pompeius had secured and executed the pirate command brilliantly was due to his talents and ambition. That he had accomplished this within a year and was thus available to step into the now deteriorated command in the East in 66 was the result of his good fortune." ${ }^{56}$

Williams explains that Glabrio was the natural choice because C. Calpurnius Piso, "a political enemy whose active hostility was demonstrated later in Gabinius' tribunate, was clearly unacceptable". ${ }^{57}$ This law effectively secured, if not the active support, the benevolent neutrality of one of the consuls of 67 and so seriously undermined the position of the remaining consul. Williams' argument that this Gabinian Law cannot be considered a prelude to the lex Manilia (de bello Mithridatico Cn. Pompeio extra ordinem mandando) does not, however, preclude the probability that Gabinius, Pompeius and Acilius Glabrio had reached some agreement towards the end of 68: a bill to award Glabrio with a promising provincial command followed by a bill to invest Pompeius with a powerful command against the pirates, both commissions being granted in triennium..$^{58}$ There is every indication that at the beginning of 67 , the

made his own replacement an easy matter when the time came." For a similar view, see also R. Seager, Pompey. A Political Biography (Oxford 1979), 32; and Keaveney 1992, op. cit. (n. 11), $120 \mathrm{f}$.

56 Williams 1984, op. cit. (n. 7), 225-230.

57 Williams 1984, op. cit. (n. 7), 230-232. An incident recorded in Dio 36.41.1f. indicates that ever since 78 there may have been bad blood between Glabrio and Lucullus. In that year, both men held the tribunate of the plebs and the praetorship successively. For the fact that even though the Calpurnii Pisones were not a monolithic bloc, they consistently opposed Pompeius and his associates well into the fifties BCE, see E.S. Gruen, 'Pompey and the Pisones', CSCA 1 (1968), 155-170.

58 Williams final conclusion on this matter (Williams 1984, op. cit. (n. 7), 233 f.: "All things considered, an interpretation that removes Pompeius from the role of Machiavellian mastermind in 67 is much more in keeping with both his military and political activities at that point in this career. Such an interpretation effectively takes into account the actions and ambitions of Gabinius and Glabrio and leads to a more balanced view of the complex political climate of the late first-century Republic. By striping away the subsequent events of Mithridates' revival and Pompeius' succession to the Eastern command, more plausible explanations emerge for the issues at hand. Gabinius appears as an able tribune establishing popularis credentials and demonstrating his effectiveness in the 
interests of $\mathrm{Cn}$. Pompeius and those of Lucullus' predominantly popularis and equestrian enemies converged, to the detriment of the Senate and its control over the administration of the provinces, both in the short and the long term.

political arena. Pompeius' amicitia with Gabinius seems to be the result, rather the cause, of the Glabrio appointment. Glabrio surfaces from obscurity as a figure who hoped to benefit through personal military glory, not one who merely served as a place-holder for the awesome Pompeius. Finally one is able to see Pompeius in a more realistic frame of reference. He did not emerge in 67 from retirement to take charge of the Roman political arena. Rather, the political scene remained what it had been: a tapestry of many ambitious men, all seeking political power, military glory, and personal dignitas. Pompeius was ultimately the greatest beneficiary of events of 67 , but still only the benefeciary.") should be qualified in this respect. 


\section{Appendix: The Provincial \\ Command of C. Calpurnius Piso}

On the basis of Dio 33.37.2 f., L. Lange suggested that this Gabinian Law also benefitted the other consul of 67, C. Calpurnius Piso, by putting him in command of Gallia Transalpina. According to Lange, this statute thus really was a lex de prouinciis consularibus rather than a lex de bello Mithridatico. ${ }^{59}$ If this were true, this Gabinian Law would have been the first of its kind in Roman history. As this study focuses on the precedent value of this largely forgotten Gabinian Law, this matter certainly deserves further scrutiny and requires a closer look at how Piso got his consular province.

In 36.37.2f., Dio relates that the Senate eventually proceeded to a reluctant ratification of the provisions of the lex Gabinia de uno imperatore contra praedones constituendo, and likewise passed such other decrees from time to time as were necessary to their effectiveness. Dio also explains that this policy was prompted more particularly by the fact that the consul Piso refused to allow Pompeius' officers to levy troops in Gallia Narbonensis, "which he (then) governed": 60

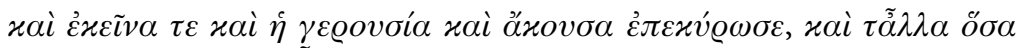

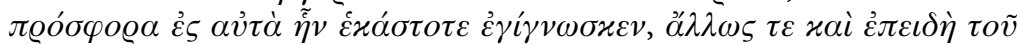

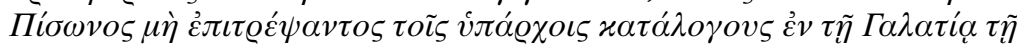

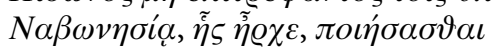

${ }^{59}$ L. Lange, Römische Alterthümer 3 (Berlin 1876, 3rd ed.), 209 f.: "da setzte sich A. Gabinius den Antrag durch, daß Bithynien nebst Pontus dem Consul M'. Acilius Glabrio als sofort anzutretende Provinz überwiesen und die Legiones Valerianae entlassen werden sollten. Bei der Kürze des einen diese lex Gabinia nennende Sallustianischen Fragments muß es dahin gestellt bleiben, ob die Lex Gabinia passender eine lex de bello Mithridatico oder eine lex de prouinciis consularibus genannt wird. Letzteres erscheint indessen wahrscheinlicher, weil der andere Consul C. Calpurnius Piso schon in seinem Consulatsjahre sich als Statthalter der Provinz Gallia Narbonensis betrachtete, obwohl er erst 688/66 dahin abging. Offenbar war es die Absicht dieser Lex Gabinia, zunächst den Lucullus, der die Provinz Asia vorläufig behielt, lahm zu legen, um dann, wenn sich M'. Acilius Glabrio, wie erwartet werden konntte, unfähig bewies, diesem und nicht direct dem Lucullus, den Pompejus als Nachfolger zu senden. Da diese Absicht sorgfältig verheimlicht wurde, so scheint der Antrag, der den Interessen der beiden Consuln entsprach, ohne Schwierigkeiten durchgegangen zu sein. Erst nachdem dieß gelungen war, aber auch noch früh im Jahre (vgl. S. 212), promulgirte A. Gabinius den zweiten, auf die Unterdrückung der Seeräuber bezüglichen Antrag ...” In the same sense (supposedly) also A.W. Zumpt, Studia Romana (1859), 55 (non vidi).

60 That Piso had been put in charge of Gallia Narbonensis is also on record in Sallust, Bellum Catilinae 49.2. 
The consul's intractable opposition so angered the commons that they "would straightway have removed him from office, had not Pompeius begged him off". ${ }^{61}$ After this incident, Dio goes on to say, Pompeius prepared his campaign as he saw fit and subsequently managed to subdue the greater part of the Mediterranean in $67 .{ }^{62}$ In Pomp. $27.1 \mathrm{f}$., Plutarch likewise records that, from Rome ( $\dot{\varepsilon}^{v} \delta \dot{\varepsilon} \mathrm{P}(\dot{\omega} \mu \eta)$ ), Piso, consumed with wrath and envy, interfered with Pompeius' equipment and discharged his crews. Pompeius therefore had to send his fleet round to Brundisium while he himself promptly returned to Rome by way of Tuscany. Since abundant provisions were meanwhile flowing into Rome, his popularity among the commons skyrocketed. Plutarch also recounts that Piso was almost deprived of his consulship and that Pompeius personally prevented the passage of a rogatio Gabinia de abrogando imperio C. Calpurnii Pisonis as well as a series of other hostile acts. Pompeius subsequently departed for Brundisium and set sail, "after arranging everything else in a reasonable matter and getting what he wanted", ${ }^{63}$ evidently by virtue of those supplementary senatus consulta on record in Dio. Plutarch sets Pompeius' intervention immediately after his preliminary campaign to purge the Tyrrhenian and the Libyan Seas and the waters about Sardinia, Corsica and Sicily, the so-called prouinciae frumentariae, an operation which reportedly took only forty days. ${ }^{64}$

Piso's last-ditch attempt to block Pompeius' designs should come as no surprise. After all, his fierce opposition against the rogatio Gabinia de uno imperatore contra praedones constituendo had almost had him lynched by a furious mob on the day of its promulgation. In 36.24.13. Dio clarifies that the senators were so outraged at this bill that they almost slew Gabinius in the curia. When the commons learned of this they turned violent and stormed the Senate-house. Dio indicates that the senators would have perished had they not fled the scene. Piso, however, boldly stood his ground, and only a personal intervention on the part of Gabinius himself saved him from being slain on the spot. ${ }^{65} \mathrm{In}$

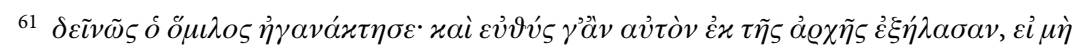
$\delta$ Понли́ı

${ }_{62}$ Dio $36.37 .3 \mathrm{f}$.

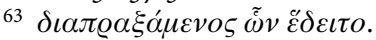

${ }^{64}$ Pompeius 26.3 $\mathrm{f}$. Plutarch explains that all his sources were unanimous on the matter of the duration of this part of Pompeius' war on piracy. Appian also attests in The Mithridatic Wars 95 that Pompeius cleared the Western basin of the Mediterranean from piracy in forty days.

65 In Pro Flacco 98, Cicero recalls that Piso had been a consul fortis constansque. 
Pompeius 25.4, Plutarch likewise relates that one of the consuls ( $\tau \tilde{\omega} v \mu \varepsilon v$ vं $\pi \dot{\alpha} \tau \omega v \not \check{\tau} \tau \varrho o \varsigma)$ was nearly lynched by a mob when he told Pompeius after the promulgation of the rogatio Gabinia that if he emulated Romulus he would share his fate. ${ }^{66}$ Further in his account of 67 Dio moreover recounts that, later that year, Piso headed the optimate opposition against the program of the tribune C. Cornelius, and how his fasces were broken to pieces by a furious crowd as a result of his raving opposition to Cornelius's intention to carry a bill reasserting the exclusive discretion of the People in matters involving exemptions from the existing laws. ${ }^{67}$

As Piso thus was one of the most zealous opponents to the rogatio Gabinia de uno imperatore contra praedones constituendo, the possibility that he had shortly before received his consular province by virtue of another lex Gabinia is highly unlikely. Lange's suggestion has therefore rightly found very little acceptance. ${ }^{68}$ It is generally assumed that Piso, also on record as governor of Cisalpine Gaul, ${ }^{69}$ got both Gauls by decree

${ }^{66}$ This note shows that Acilius Glabrio was still in Rome at this time, which suggests that this Gabinian bill, too, must have been promulgated and passed sometime early in 67.

67 Dio 36.39.3. For the fact that Piso's fasces were broken in consequence of his opposition against this bill, see also Asconius, Pro Cornelio 1, p. 48 (ed. Stangl 1912). In 36.38 , Dio asserts that in 67 , the Senate ordained both consuls to frame a law de ambitu, in reaction to C. Cornelius' far more severe bill on bribery. In $39.1 \mathrm{f}$., Dio indicates that since the (consular) elections had already been announced and accordingly no law could be enacted till they were held, the Senate voted that the law should be introduced before the elections and that a body-guard should be given "to the consuls". Cornelius angrily responded by proposing to make the People the sole source of exemption from the laws. In 36.39.3, Dio goes on to say that this particular bill caused the uproar wherein Piso's fasces were broken. At first sight, one might deduce from Dio's representation that Acilius Glabrio was still in Rome around mid-67. However, as Cicero, Pro Murena 46; 67, Asconius p. 68; 75; 89 and Scholia Bobiana p. 361 (ed. Orellius 1833) invariably mention a lex Calpurnia (de ambitu), not a lex Calpurnia Acilia, and since only Piso took the lead of the optimate opposition against Cornelius' rogation de legibus soluendo, it is better to conclude that Dio is mistaken in that Acilius Glabrio was no longer in Rome at the time of the political turmoil caused by these two Cornelian bills. The Senate might have simply referred to the generic plural in its decree concerning a body-guard for Piso. This also implies that the definition of this law as a 'lex [Acilia] Calpurnia de ambitu' (e.g., G. Rotondi, Leges Publicae Populi Romani (Milano 1912), 374; C. Macdonald in the 1996 [= 3 rd] Loeb edition of Cicero's Pro Murena, 174), ought be discarded in favour of 'lex Calpurnia de ambitu' tout court.

${ }^{68}$ Rotondi 1912, op. cit. (n. 67), 373 makes mention of a "Lex Gabinia (de provinciis consularibus?)". Gelzer 1943, op. cit. (n. 40), 41 n. 7 takes note of Lange's suggestion but stops short of expressing his own view on the matter. Gelzer leaves aside the question whether Piso in 67 received Cisalpina, too.

${ }^{69}$ See Ad Atticum 1.1.2 (Rome, shortly before 17 July 65), where Cicero tells Atticus 
of the Senate, and that at least the Cisalpine province was assigned during his actual term of office. ${ }^{70}$ In my opinion, Dio does not offer any relevant information in $36.37 .2 \mathrm{f}$. concerning the procedure by which Piso got Gallia Narbonensis. Although Dio's fairly extensive report of 67 (from 36.12 to 36.42 .2 ) is partially lost (the bits from 36.17 .3 to 36.18 , and from 36.36.4 to 36.37), it looks as if he didn't make any mention of the Gabinian Law on behalf of the consul Acilius Glabrio. Dio's narrative rather revolves chiefly around the lex Gabinia de uno imperatore contra praedones constituendo (36.20-36.37.1). Neither does Dio indicate that Piso's colleague got his attractive provincial command by means of a popular vote, something he could have done perfectly in, for example, 36.14.4; 15.3 and 17.1 .

Anyhow, the information provided by Dio and Plutarch is not at all inconsistent or contradictory. ${ }^{71}$ Both sources clearly show that in the immediate aftermath of Pompeius' appointment to his second extraordinary proconsulship by virtue of the Gabinian Law, Piso proactively tried to prevent him from making the necessary preparations and apparently did so wherever he felt entitled to, viz. in Gallia Narbonensis, his prouincia decreta, as well as in Italy. ${ }^{72}$ That Piso staged this interference as consul

that he planned to serve on Piso's staff in (Cisalpine) Gaul from September 65 to January 64, and Sallust, Bellum Catilinae 49.2.

${ }^{70}$ Willems 1883 , op. cit. (n. 6), 577 n. 1 suggests that Piso got Gallia Narbonensis under the terms of the Sempronian law, and argues (578) on the basis of Dio 36.37 that Piso governed this province in 67 in absentia, through legates. Gelzer 1943, op. cit. (n. 40), 41 n. 7 observes that Willems "Wohl unrichtig bezieht ... die Diostelle 578, 4 auf Legaten des Piso, und so bleibt fraglich, ob er seine Provinzen schon durch Senatsbeschluß erhalten hatte." With reference to Dio 36.37.2 f., Broughton $(M R R 2$, 143) claims that Gallia Transalpina, too, was given to Piso during his consulship. N.J. Woodall, A Study of the Lex Sempronia de Provinciis Consularibus with reference to the Roman constitution and Roman politics from 123 to 48 B. C. (Dissertation State University of New York at Albany 1972), 89 f., however, believes that this passage from Dio does not rule out the possibility that Transalpina was assigned lege Sempronia, although uncertainty remains.

${ }^{71}$ Contra H. Siber, Das Führeramt des Augustus (Leipzig 1940), 29 where it is argued that Dio caused confusion to the extent that he mixed up "den von Plutarch Pompeius 27, 1 erzählten Widerstand, den Piso als Konsul 67 den Rüstungen in Italien geleistet hatte, mit einem Fall, der sich erst in den Jahren seiner prokonsularen Statthalterschaft in der Narbonensis 66/ 65 zugetragen haben kann”. Gelzer 1943, op. cit. (n. 40), 41 n. 7 thinks it unlikely that Dio would not have extracted this detailed information directly from one of his sources, and correctly adds that "Plutarch, der von Entlassung der Schiffsmannschaften spricht, kann zur Not auch damit vereinbart werden."

72 As is clear from Plutarch, Pompeius 27.1. 
from Rome is particularly interesting. ${ }^{73}$ Normally, any imperator could only exercise his imperium in his prouincia decreta from the moment he had physically entered this prouincia, the so-called traditio imperii being the embodiment of the actual assumption of the right to wield one's imperium in one's decreed province. ${ }^{74}$ Piso's notable (and noted) interference from Rome suggests that he might have felt entitled to do so in consequence of a more or less unusual situation. As Lange's erroneous assumption that Piso interfered in Narbonensis because he was given this province by virtue of a law fails to explain why Piso apparently also tampered with Pompeius' equipment in Rome and Italy, ${ }^{75}$ this question requires a more plausible explanation.

To my thinking, the highly strategic concentration of both the Gallic provinces under the command of the consul Piso suggests an unusual arrangement made in the face of an exceptional situation. Possibly, the Senate had assigned both Gauls in 68 to the consuls of 67, in accordance with the provisions of the Sempronian Law. While the lex Gabinia on behalf of Acilius Glabrio doubtlessly sullied the prestige of the Senate and must have offended proud nobles like Piso, Pompeius' subsequent election to a position of unprecedented and unparalleled power doubtlessly caused far greater concern amongst the vast majority of senators, now fearful of outright military despotism. ${ }^{76}$ It is, therefore, quite possible that the rogatio Gabinia against piracy prompted the Senate to assign both the Gallic provinces sine sorte to the 'loyal' consul. This would create a powerful safeguard to protect Rome and Italy against any possible Pompeian coup détat. ${ }^{77}$ On the strength of this strong senatorial backing and his consulship, which theoretically still made him one of two summi imperatores in charge of the Republic and the provinces of the Roman Peo-

${ }^{73}$ Compare also Gelzer 1943, op. cit. (n. 40), 41, n. 7, who remarks that if Lange would be right and Piso did owe his province to a lex de prouinciis consularibus, "so ergäbe sich die wichtige Erkenntnis, daß Piso, obwohl noch als Konsul in Rom amtierend, sich berechtigt fühlte, in der ihm durch Plebiszit übertragenen Provinz derartige Verfügungen zu treffen."

${ }^{74}$ See Chapter 4 (Summum imperium auspiciumque and prouincia) of my forthcoming monograph on The Roman High Command. The Principle of the summum imperium auspiciumque under the Roman Republic.

75 Plutarch, Pompeius $27.1 \mathrm{f}$.

${ }^{76}$ See, for example, Dio 36.24.1 f.; Plutarch, Pompeius 25.3 f.

77 After all, Pompeius had already ruthlessly abused his legions to impose his will upon the Senate in 80, 77 and 71: Vervaet 2009, op. cit. (n. 46). In all likelihood, Gabinius and his associates refrained from obstructing this decree not to endanger their own projects for 67 by pushing Piso and the Senate to the limits. 
ple, ${ }^{78}$ Piso perhaps felt strong enough to interfere with Pompeius' equipment in Italy and his prouinciae decretae. In the face of what he and most of his senatorial peers perceived as a formidable threat to the Republic, he may have simply felt that it was his duty to obstruct Pompeius rei publicae causa, even if this meant a measured breach of prevailing rules and restrictions. ${ }^{79}$ Both Gabinius and Pompeius must have subsequently made it clear to Piso that he had no right whatsoever to exercise his imperium in his decreed provinces in absentia, ${ }^{80}$ and that he was furthermore obstructing the execution of the provisions of a tremendously popular piece of comitial legislation. In all likelihood, Gabinius framed his bill to abrogate Piso's imperium as a clear warning that, once stripped of office, he could and would be prosecuted for violations of the lex Cornelia maiestatis. ${ }^{81}$ Both Dio and Plutarch explicitly attest that only after Gabinius and next Pompeius himself had brought the recalcitrant consul to reason, the Senate reconciled itself with the facts by passing a series of decrees in support of Pompeius' equipment efforts as provided for in the Gabinian law. ${ }^{82}$ This was not the end of this bitter feud, though, as Piso

${ }^{78}$ For a discussion of this theoretical Republican constitutional doctrine, see Chapter 6 (The consuls and the prouinciae Populi Romani) of my forthcoming monograph on The Roman High Command. The Principle of the summum imperium auspiciumque under the Roman Republic.

79 As Piso's interference seems to have been limited to Italy, traditionally a consular sphere of power, and his decreed provinces, he apparently decided to act with calculated measurement. See, for example, Cicero, Pro Rabirio Postumo 19 (Gabinius se id fecisse dicebat rei publicae causae, quod classem Archelai timeret, quod mare refertum fore praedonem putaret) for the fact that legislation restricting certain activities and movements on the part of provincial commanders (maiestatis, repetundarum) allowed for exceptions on an ad hoc basis and rei publicae causa, in the best interest of the Republic. Obviously, invoking such discretionary clauses in court would require a very strong defence argument.

${ }^{80}$ Lange wrongly supposes that a lex Gabinia de prouinciis consularibus had empowered Piso to exercise his imperium in his province in absentia. In my opinion, Cn. Pompeius was the first proconsul ever to receive the right to administrate his provinces in absentia, while remaining in Italy and through legati pro praetore: Velleius 2.48 .1 and Dio 39.39.4. Pompeius got this privilege by virtue of the Trebonian Law of 55, the exception being officially made rei publicae causa, in order in order to allow Pompeius to continue his curatio annonae: Caesar, De Bello Gallico 6.1; Dio 39.39.4.

${ }^{81}$ Not quite correctly, Williams 1973, op. cit. (n. 24), 68 styles this move on the part of Gabinius as "an unprecedented step which would have been truly revolutionary had it been carried out." For abrogatio imperii usually being the first step towards criminal prosecution, see R.A. Bauman, 'The abrogation of imperium, some cases and a principle' RhM 111 (1968), 37-50.

${ }^{82}$ Dio 36.37.1 f.; Pompeius 27.2, cf. supra. 
was eventually prosecuted de pecuniis repetundis in 63 for facts allegedly committed in Transpadane Gaul, Caesar being among the advocates of the provincials. ${ }^{83}$

Melbourne, November 2009

${ }^{83}$ Cicero, Pro Flacco 98; Sallust Bellum Catilinae 49.2. 